\title{
IAMJ
}

INTERNATIONAL

AYURVEDIC

MEDICAL JOURNAL

\section{PURIFICATION OF AIR BY LAKSHAHARIDRAADI YOGA AND SOME MEASURES TO REVERSE THE IMPACT OF POLLUTED AIR}

\author{
Jayanti Jain $^{1}$, Ritu Kapoor ${ }^{2}$, Manoj Adlakha ${ }^{3}$ \\ ${ }^{1}$ MD scholar, P.G Dept, Agad Tantra Evam VyavaharAyuveda, DSRRAU, Jodhpur, Rajasthan, India \\ ${ }^{2}$ Associate Professor \& HOD, P.G Dept. Agad Tantra Evam Vyavahar Ayurveda, DSRRAU, Jodhpur, Rajasthan, \\ India \\ ${ }^{3}$ Associate Professor, P.G Dept, Dravya Guna Vinjana, DSRRAU, Jodhpur, Rajasthan, India
}

Corresponding Author:ajmerajaya1994@gmail.com

https://doi.org/10.46607/iamj4309092021

(Published Online: September 2021)

Open Access

(C) International Ayurvedic Medical Journal, India 2021

Article Received:28/08//2021 - Peer Reviewed:04/09/2021 - Accepted for Publication:05/09/2021

\section{Check for updates}

\begin{abstract}
Environment plays a very significant role in human civilization. Human beings have close relations with the biosphere in which they live. The whole environment and ecology consisting of earth, air, water, plants and animals provide the necessary and sufficient conditions for sustaining human life. In Yajurveda and Vedic sages pure water, air etc. are the roots to good health and happiness and hence they considered all these as gods. The Vedic people desired to live a life of hundred years and this wish can be fulfilled only when the environment will be unpolluted, clean, and peaceful. Today, the environmental crisis is a tremendous problem for the whole world as it is suffering from environmental pollution. Therefore, today environmental problems have been the object of discussion everywhere from village to parliament. Air Pollution is by far the most rapidly growing problem of modern technological society. Although the world has already addressed this issue and has also taken steps to minimize it a lot more than this is needed. The damage which our hunger for ease of living had already caused is irreparable by just making laws, rules \& regulations. We need strong implementation of it as well as general awareness and contribution from everyone. Ayurveda can play a vital role in fighting this battle for cleaning the air and minimizing air pollution; it could even emerge as 'SanjeevaniBooti'. There's no need of proving the worth of Vedic sci-
\end{abstract}


ence to our society as it is now worldwide accepted and part of everyone's life. Recent Ayurveda studies have shown positive results in dealing effectively with the evil of air pollution.

Keywords: Ayurveda, Air pollution, Fumigation, Lakshaharidraadi Yoga

\section{INTRODUCTION}

Mother Nature has granted us so many precious gifts. Air is among one of those gifts, which is essential for the survival and existence of all living things. It provides oxygen and other gases which is necessary for respiration and cellular metabolism. In the event of severe air pollution, instant death is inevitable. Every second million and billions of small particles and substances are being introduced into our environment which directly or indirectly affects our lives and ecosystem in a very destructive manner. Those events could be triggered by natural phenomena like volcanic eruptions, land sliding etc., but most of the polluting events are caused by human interference with nature. As we already know the whole world is fighting a war for pure air as the packaging of fresh air has also been started in many parts of the world and people are paying for fresh air. India is also one of the main countries in which people are suffering from polluted air. AQI (Air Quality Index) of India has a very bad statistic and according to some reports, India has 21 cities in the top 30 polluted cities in the world $^{[1]}$. According to the latest report, Delhi has scored AQI 393 with a particulate matter of 2.5 while Rajasthan Jodhpur has emerged as the most polluted city with AQI 338 and these scores are hazardous to human health and the planet as a whole ${ }^{[2]}$. Besides this WHO also estimates that 7 million people die every year due to polluted air. About $24 \%$ from cardiovascular disease deaths, $43 \%$ from chronic obstructive pulmonary deaths, $25 \%$ from stroke deaths, $29 \%$ from lung cancer deaths worldwide occur mainly due to rapid urbanization, industrial development and also due to the rapid increase in uses of combustion technologies. ${ }^{[3]}$ As we have seen the dreadful consequences of polluting air, we need to know about the sources and hazardous effects of air pollution and measures to reduce or prevent the effects of polluting air.

\section{SOURCES OF AIR POLLUTION ${ }^{[4]}$}

Before discussing the hazardous effect of air pollution, we have to know the causes of air pollution. The main causes of air pollution are -

a) AUTOMOBILES - Motor vehicles, railways, ships, aeroplanes etc. are the main sources of air pollution. They release hydrocarbons, oxides of nitrogen, particulate matter, $\mathrm{CO}$, smoke, malodorous fumes etc. in the atmosphere.

b) INDUSTRIES -Factories of iron and steel, thermal power plant, petrochemical industries, petroleum refiners etc. emit a large number of pollutants like $\mathrm{CO}, \mathrm{SO}_{2}, \mathrm{H}_{2} \mathrm{~S}, \mathrm{NO}_{2}$, fly ash etc., into the atmosphere.

c) DOMESTIC SOURCES -Combustion of coal, wood and oil is the major source of smoke, $\mathrm{SO}_{2}$, dust and $\mathrm{NO}_{2}$. In 1952, in the London disaster, thousands of people died due to domestic coal burning.

d) MISCELLANEOUS - Tobacco smoking, nuclear explosions, volcanoes, incinerators, burning of refuse, spraying of pesticides and natural sources like wind-borne dust, fungi, mould, bacteria etc., all these sources contribute to air pollution.

\section{AIR POLLUTANTS ${ }^{[5]}$}

Air pollutants are mainly of two types:

a) Primary air pollutants - Primary air pollutants are those pollutants that are emitted from sources directly into the atmosphere.

b) Secondary air pollutants - Secondary air pollutants are those pollutants that are formed within the atmosphere itself.

More than 100 substances are identified that are polluted air. Among the most common air pollutants are-

i. CARBON MONOXIDE - It is one of the most common and widely distributed air pollutants formed from the combustion of carbon- 
containing materials such as coal, incinerators, automobiles, industrial process etc.

ii. SULPHUR DIOXIDE - There are several forms in which sulphur exists in the air such as $\mathrm{SO}_{2}$, $\mathrm{H}_{2} \mathrm{~S}, \mathrm{H}_{2} \mathrm{SO}_{4}$ and sulphate salts. $\mathrm{SO}_{2}$ is formed due to the combustion of sulphur-containing fossil fuel, domestic fires, power generation etc.

iii. LEAD - Lead is a heavy metal that is naturally found in the environment and in manufactured products. Major sources of lead are lead smelters, waste incinerators, metal processing etc.About $80-90 \%$ of lead in ambient air release from the combustion of leaded petrol.

iv. CARBON DIOXIDE -It is an important heattrapping (greenhouse) gas that is released in the atmosphere through the natural process like respiration, volcanic eruptions, etc. as well as through human activities like deforestation and burning fossil fuel.

v. OZONE-Ozone is a very helpful gas when it is in the stratosphere as it protects us from harmful rays like Ultraviolet, but on the ground, it is a highly toxic gas. It is also responsible for global warming when present near the ground. Ground ozone is formed by a Chemical reaction between oxides of nitrogen and a volatile organic compound.

vi. OXIDES OF NITROGEN- Oxides of nitrogen is formed by a chemical reaction between nitrogen and oxygen mainly by the motor vehicles during the combustion of fuel. It is also one of the major constituents which plays a main part in the pollution of air as it is highly dangerous gases.

vii. HYDROCARBONS -Sources of hydrocarbon include incineration, combustion of coal, wood and use of petroleum. Hydrocarbons chemically react in the atmosphere and cause photochemical smog.

viii. CADMIUM - Large emission of cadmium is from steel industries, waste incineration, volcanic action and zinc production.

ix. HYDROGEN SULPHIDE-Hydrogen sulphide is produced in industries like rayon, paper, tar distillation and natural gas refining. x. POLYCYCLIC AROMATIC HYDROCARBONS (PAHs) - PAHs are formed by incomplete combustion of organic fuel. It is also formed by thermal activities like volcanic eruptions and forest fires due to the incomplete combustion of biomass. It can exist in both gases and particulate states, and it can cause lung cancer and other serious liver and kidney disease.

xi. PARTICULATE MATTER- Particulate matter is a broad term used to indicate molecules of different origins suspended in the air. It can be dust pollen or minerals. It is classified into two categories by its molecular size i.e. $\mathrm{PM}_{10} \& \mathrm{PM}_{2.5}$. $\mathrm{PM}_{10}$ refers to any particle which has a diameter of 10 microns or less \& $\mathrm{PM}_{2.5}$ refers to any particle which has a diameter of $2.5 \mu \mathrm{m}$ or less. $\mathrm{PM}_{10}$ is inhalable, so it can get into our lungs and cause breathing problems and even asthma. $\mathbf{P M}_{2.5}$ is also inhalable but is very small in size so it can get deep into our lungs \& even pass through our blood-brain barrier and reaches the heart and cause some serious cardiovascular and other health complication.

\section{HAZARDOUS EFFECT OF AIR POLLUTION}

A) Air pollution is responsible for a wide range of diseases in human beings. It can cause as simple as flu-like symptoms to chronic asthma. It can also cause some serious cardiovascular disease, respiratory disorders, and damage major body organs. Some research has suggested that it is one of the main reasons behind many types of cancers in humans.

B) Day by day ozone is depleting due to air pollution. Due to the depletion of the ozone layer, ultraviolet rays can easily reach the earth's surface and cause some serious skin trouble like skin cancers in humans.

C) Due to air pollution so many people have developed allergies to many agents and particulate matters that are suspended in the air. In the long term, it is also responsible for so many autoimmune disorders in humans.

D) Air pollution leads to global warming which further leads to the melting of ice. So, in that way, wildlife, and plants species in the region of cold climate 
are also in danger of getting extinct due to the temperatures rise. It is also feared by so many scientists that many viruses are packed in the glacier for thousands of years and the melting of those glaciers could also activate those viruses and thus can cause a pandemic.

E) Industrialization and heavy transportation lead to the formation of sulphur dioxide and nitrogen dioxide. When those gases go up in the air and react with water, they form sulphuric acid and nitric acid which get mixed with rain responsible for many skins related problems and also damages too many buildings.

\section{INDICATORS OF AIR POLLUTION ${ }^{[6]}$}

Following indicators are used for monitoring air pollution.

1) Sulphur dioxide-Some people experience difficulties in respiratory \& pulmonary functions after exposure to $\mathrm{SO}_{2}$ even for a short duration of time. Some studies indicate that the average duration of 10 minutes should not be exceeded when people came in contact with a $500 \mathrm{ug} / \mathrm{m} 3$ concentration of $\mathrm{SO}_{2}$.

\section{Table no.1- Air pollution index}

\begin{tabular}{|l|l|l|l|}
\hline AQI & Remark & Colour Code & Possible Health Impacts \\
\hline $0-50$ & Good & Dark green & Minimal health implications \\
\hline $51-100$ & Moderate & Light green & May causes minimal breathing difficulties in sensitive people \\
\hline $101-200$ & Unhealthy & Yellow & $\begin{array}{l}\text { Breathing difficulties to the people with lung disease, asthma, } \\
\text { heart disease and children and older adults }\end{array}$ \\
\hline $201-300$ & Very Unhealthy & Orange & $\begin{array}{l}\text { Breathing discomfort in people on prolonged exposure and } \\
\text { people with heart disease }\end{array}$ \\
\hline $301-400$ & Hazardous & Light red & $\begin{array}{l}\text { Respiratory illness on prolonged exposure and people with } \\
\text { lung and heart disease }\end{array}$ \\
\hline $401-500$ & Emergency & Dark red & $\begin{array}{l}\text { Affects healthy people and has severe impacts on people with } \\
\text { lung and heart disease }\end{array}$ \\
\hline
\end{tabular}

5) Coefficient of haze- A factor used in evaluating the amount of smoke or other aerosols per cubic meter in the air.

6) Other - Other parameters are lead, carbon monoxide, nitrogen dioxide, oxidants.

PREVENTION AND CONTROL OF AIR POLLUTION [9]

Different procedures for prevention and control of air pollution are recommended by WHO-

a) CONTAINMENT - Prevention of escape of toxic substances into the atmosphere.
Sulphur dioxide air pollution index ${ }^{[7]}$
a) $0-0.1 \mathrm{ppm}$
Good
b) $0.1-0.2 \mathrm{ppm}$
Moderate
c) $0.2-1.0 \mathrm{ppm}$
Unhealthy for sensitive group
d) $1.0-3.0 \mathrm{ppm}$
Unhealthy
e) $3.0-5.0 \mathrm{ppm}$
Hazardous

2) Smoke or soiling index - Soiling index is a measurement of soil properties of suspended particles in one cubic meter of air. A measured volume is filtered through white filter paper and discolouration produced is measured by a photoelectric meter.

3) Suspended particles-Measurement of dust and grit concentration in the given volume of air by using an instrument 'Midget impinger' and is expressed in mgper cubic meter of air.

4) Air pollution index ${ }^{[8]}$-The air quality index is an arbitrary index based on the measurement of particulate matter $\left(\mathrm{PM}_{2.5}\right.$ and $\left.\mathrm{PM}_{10}\right)$, Ozone $\left(\mathrm{O}_{3}\right)$, Nitrogen dioxide $\left(\mathrm{NO}_{2}\right)$, Sulphur dioxide $\left(\mathrm{SO}_{2}\right)$ and Carbon monoxide (CO) emissions as the severity of pollution. b) SUBSTITUTION -Substitution of technology causing air pollution with a process that does not affect the air quality

c) DILUTION - Making establishments of 'green belts' mandatory between areas for diluting the condensed air.

d) LEGISLATION - Framing of strict rules and regulations (Laws) by government and more than that ensuring proper implementation of the same

e) COLLECTIVE INTERNATIONAL APPROACH - To effectively deal with air pollution 
on a worldwide scale, WHO has established an international network of laboratories for the monitoring and studying air pollution, more such steps are needed.

AYURVEDIC MEASURES TO PURIFY AIR AND REDUCE HARMFUL EFFECTS OF POL-

\section{LUTED AIR}

Birds start falling from the sky in serious conditions; it indicates that the whole air is getting poisoned. It further affects people (inhaling and dealing with the same poisoned and polluted air) adversely with cough, nasal discharge, headache, and severe eye diseases. ${ }^{[10]}$ To prevent the repercussions of poisoned air, the atmosphere should be purified by burning herbal drugs mentioned in the table no. 2 in the open ground as fumes of these drugs are capable and effective in purifying the air ${ }^{[11]}$.

In Ayurvedic Literatures many formulations or Yogas are mentioned for the purification of air. Among them Lakshaharidraadi Yoga is one which is known for its properties for purification of air is mentioned in Kalp sthan of Sushrut Samhita is described below-

Table 2: LAKSHAHARIRAADI YOGA ${ }^{[11]}$

\begin{tabular}{|c|c|c|c|}
\hline S.N & DRUG & LATIN NAME & PROPERTIES \\
\hline 1 & Laksha & Laccifera lacca & Anti-Inflammatory, HepatoProtective. ${ }^{[12]}$ \\
\hline 2 & Haridra & Curcuma longa & $\begin{array}{l}\text { Anti-bacterial, Anti-microbial, Insecticidal, Anti-fungal, Anti-viral, } \\
\text { Anti-protozoal, Antioxidant, Hepatoprotective, Anti-Inflammatory, } \\
\text { Anti Carcinogenic. }{ }^{[13,14]}\end{array}$ \\
\hline 3 & Ativisha & Aconitum heterophyllum & $\begin{array}{l}\text { Anti-Bacterial, Anti-Pyretic, Antispasmodic, Immunomodulator, } \\
\text { Anthelminthic. }{ }^{[15]}\end{array}$ \\
\hline 4 & Abhaya & Terminalia chebula & Anti-Microbial, Anti-Fungal, Anti-Bacterial, Antihelminthic. ${ }^{[16]}$ \\
\hline 5 & $\begin{array}{l}\text { Mustha } \\
\text { (Abda) }\end{array}$ & Cyperus rotundus & $\begin{array}{l}\text { Anti-bacterial, Anti-cancerous, Anti-Inflammatory, Anti-malarial, } \\
\text { Anti-mutagenic, Antioxidant, Hepatoprotective, Cardioprotective, } \\
\text { Neuroprotective. }^{[15]}\end{array}$ \\
\hline 6 & $\begin{array}{l}\text { Nirgundi } \\
\text { (Harenuka) }\end{array}$ & Vitex nirgundo & $\begin{array}{l}\text { Anti-Inflammatory, Antibacterial, Mosquito Repellent, Hepatopro- } \\
\text { tective, Anti-Microbial, Anti-Tumor, Immunomodulator. }{ }^{[17]}\end{array}$ \\
\hline 7 & Ela & Elettaria cardamomum & $\begin{array}{l}\text { Anti-Bacterial, Anti-Fungal, Anti-Viral, Antiseptic, Antioxidant, } \\
\text { Hepatoprotective, Cardioprotective, Immunomodulator. }{ }^{[18]}\end{array}$ \\
\hline 8 & $\begin{array}{l}\text { Tagar } \\
\text { (Vakra) }\end{array}$ & Valeriana wallichi & $\begin{array}{l}\text { Anti-Pyretic, Antibacterial, Antibiotic, Antioxidant, Anti- } \\
\text { inflammatory. }{ }^{[19,20]} \text {. }\end{array}$ \\
\hline 9 & Kustha & Saussurea lappa & $\begin{array}{l}\text { Anti-Cytotoxic, Anti-bacterial, Anti-viral, Anti-parasitic, Anti In- } \\
\text { flammatory, Immunostimulant, Antioxidant. }{ }^{[21,22]}\end{array}$ \\
\hline 10 & Priyangu & Callicarpa macrophylla & $\begin{array}{l}\text { Anti-Inflammatory, Blood Purifier, Anti-Tumor, Anti-Bacterial, } \\
\text { Anti-Fungal. }{ }^{[23]}\end{array}$ \\
\hline
\end{tabular}

Drug of Lakshaharidraadi yoga possess properties like antioxidant, anti-microbial, anti-fungal, antiinflammatory, anti-septic, which helps in purifying the air (absence of microbes in the air). Not only this, but it is also effective in increasing the immunity of persons and reducing or counteracting the impacts on a person due to the polluted air.

Acharaya Charak has also mentioned some other fumigation formulations or Yogas that detoxifies the polluted air and poison presents in the surrounding area in Vishachikitsaadhyay of Chikitsa sthan ${ }^{[24]}$
* Fumigation of powder of feathers of the peacock, bones of swan, Yellow Mustard (Brassicacampestris L.) and Chandana (Santalum album L.) + Ghrita (Clarified butter) is effective if poison is there in house, clothes and bed. Also, its fumes help in purifying polluted air.

* Fumigation of a combination of Tagar (Valeriana wallichii DC.), Kusthha (Saussurealappa C.B. Clarke), the flower of Shirisha (Albizzia lebbeck Benth.) helps in killing all kinds of toxic substances present in the air thus purify the air. 
* Fumigation of Laksha ( Laccifera lacca), Usheer (Vetiveria zizanioidis), Tejpatra (Cinnamomum tamala), Guggulu (Commiphora mukul), Bhallatak (Semicarpus Anacardium L.), the flower of Arjuna (Terminalia arjuna Roxb.), Raal (Extract of Shorea robusta Gaertn.), White Aparajita (Clitoria ternatea L.) all these drugs should be taken in equal quantity and mixed with ghrita (clarified butter) and this fume will help in killing snake, rat, insects and also kills the small moths which live in our clothes. This fume is also effective in purifying polluted air.

\section{RECENT STUDIES -}

$>$ Medicinal smoke reduces airborne bacteria. ${ }^{[25]}$

This study represents the effect of the smoke of natural products and its ethnopharmacological aspects on airborne bacterial composition. The airborne bacterial population is treated by smoke which is originated from the burning of wood and a complex mixture of odoriferous and medicinal herbs (havan samagri) like Aegle Marmelos, Cedrus deodara, etc. Obtained results show that after 1-hour treatment of medicinal smoke there is a $94 \%$ reduction of bacterial count, and this is effective up to $24 \mathrm{hrs}$ in a closed room and this smoke can purify or disinfect the air and make the environment more clear and healthy.

\section{$>$ AGNIHOTRA - A non-conventional solution} to air pollution. ${ }^{[26]}$

This research work is completely based on laboratory work. This study was conducted under natural lab conditions and local artificially created indoor air pollution. For the study they are using 324 Ahuties yagya with materials like cow ghee, Pipal wood ( $F i$ cus religiosa), HavanSamagri (Kapurkachari, Gugal, Nagarmotha, Jatamansi, Sughandhbela, Illayachi, Jaypal, Cloves, Dalchini etc.), after Ahuties in Yagya we noticed that there is a significant reduction in the concentration of $\mathrm{SO}_{\mathrm{x}}, \mathrm{NO}_{\mathrm{x}}$ by almost $51 \%$ and $60 \%$ respectively more by Yagya when compared without Yagya.

$>$ Preparation and evaluation of Herbal Dhoop for cleansing the air. ${ }^{[27]}$
The current research work focuses on the preparation and evaluation of a natural Dhoop stick instead of using chemical and harmful UV rays, for decreasing the count of aeromicroflora. For the study herbal dhoop was prepared by using agents like Cow dung, Cow ghee, Cow milk, Camphor (Cinnamomum camphora), Guggul (CommiphoraMukul), Dhoop (Boswellia serrata), Kapurkachri (Hedychium spicatum) and Anantmula (Hemidesmus indicus) Microbiological evaluation was conducted with Nutrient and Sabouraud Agar plates (in duplicates) which exposed in various areas such as restaurant kitchen, households, washroom, hospitals etc. We observed that there is a significantly decrease in the count of aeromicroflora by using an herbal Dhoop stick.

\section{$>$ PLANTATION ${ }^{[28}$}

As we already know plants gives us lots of benefits They remove carbon dioxide from environment by photosynthesis process and release oxygen into the air. In addition to regulating temperature, humidity, air movement, they are also interacting with air and helps in removing pollutants from the environment in various ways. Some household plants can naturally improve the quality of air and cleanse the air like the Snake plant, Aloe vera, Pothos, Dracena, Spider plant, Rubber plant, Monestra Deliciosa, Peace lily etc. All these plants help in removing indoor air toxins like benzene, xylene, trichloroethylene and formaldehyde.

\section{SOME WAYS FOR REVERSING THE HARM-} FUL EFFECTS OF AIR POLLUTION

$>$ NASYA KARMA -It is one of the Panchkarma procedures that is used to prevent allergies inside the nostril caused by pollutants in the air. This procedure can be done by using two drops of medicated oil in each nostril in the morning and during bedtime at home. It not only flushes pollutants but also prevents the pollutants to cross the nasal pathway. It is also known as nasal drop treatment. ${ }^{[29,30]}$

$>$ YOGA and PRANAYAM-With increases air pollution, it's important to introduce yoga and pranayam into your daily routine life. Like the daily practice of yoga even for a short $10 \mathrm{~min}$ is rec- 
ommended because it will help strengthen your lungs, cleanses your nasal passage and also helps in improving respiratory functions. The most important practice to strengthen the lungs is the pranayam. Pranayam is the set of breathing exercises and patterns i.e. Puraka (inhalation), Kumbhaka (retention or hold your breath) and Rechaka (Exhalation) in a specific sequence. ${ }^{[31]}$ Practicing some breathing techniques like $k a$ palbhati, a cleansing kriya, followed by anulom vilom - a balancing and rejuvenation pranayam helps to detoxify the body and improve your lung functions. Some other breathing exercises are alternate nostril breathing i.e. Nadishodhan, victorious breath i.e. Ujjayi, female honey bee humming i.e. Brahamrietc. ${ }^{[32,33]}$

$>$ DIET AND HERBS - Always use freshly cooked warm food. To strengthen the immune system, we need a diet rich in antioxidants to protect our body from the adverse effect of air pollutants. We should consume Amla, Tulsi, Turmeric, Ghee, Pipali, Triphala etc. on regular basis to nullify the harmful effect of pollutants and improve the function of the respiratory system.

\section{CONCLUSION}

As mentioned above the availability of fresh air is already difficult and it's even on sale. According to the current speed with which air pollution is widening up its feather in our environment that day is not far when the only option to have 'Praan' (life) is to purchase 'Praan Vaayu' (clean and healthy air). It's high time that no stone shall be left unturned to minimize, prevent and stop air pollution. We have already addressed the problem, causes as well as hazardous effects. We must do whatever it takes to save mother Earth which blessed us with this blissful life to get rid of its sickness (pollution) which would help in providing a healthy, safe and peaceful environment to us and our coming generations.

Ayurveda is also playing its part in this battle already but there's much more which is left unexplored or unknown to us. Our study concludes that usage of
Lakshaharidraadi Yoga, Agnihotra etc., could be very effective in dealing with air pollution. The smoke of some herbs can be useful in cleaning the air, detoxification of environment and improving AQI. Vedic science and literature have a very rich heritage as well as possibilities. It is capable of joining hands with modern science and technology in fighting this battle against air pollution. More such studies must be encouraged to make our environment free of pollution and by putting the cumulative knowledge and efforts of both Ayurveda Science and Modern Technology some devices can be made which by using Ayurvedic Herbs (like Neem, Guggu$l u$,etc.) can naturally reduce the pollution.

\section{REFERENCES}

1. https://www.iqair.com/india

2. https://timesofindia.indiatimes.com/city/jodhpur/jodhp ur-the-most-polluted-city-inrajasthan/articleshow/66470631.cms

3. https://www.ccacoalition.org/en/news/world-healthorganization-releases-new-global-air-pollution-data

4. Park, K., Park's textbook of Preventive and Social Medicine. M/s Banarsidas. Bhanot, Jabalpur, India, Twenty-second edition, 2009; 13, pp. 681

5. Park, K., Park's textbook of Preventive and Social Medicine M/s Banarsidas. Bhanot, Jabalpur, India, Twenty-second edition, 2009; 13, pp. $680-682$

6. AH Suryakantha, Community Medicine with Recent

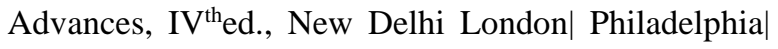
Panama, The Health Sciences Publisher2017-page no. 49

7. https://www.nps.gov/subjects/air/humanhealthsulfur.htm

8. https://app.cpcbccr.com/AQI_India/

9. Park, K., Park's textbook of Preventive and Social Medicine M/s Banarsidas. Bhanot, Jabalpur, India, Twentieth edition, 2009; 13, pp. 645

10. Murthy, K.R.S., Sushruta Samhita, Chaukhambha orientalia, Varanasi, India, Kalpasthan, 2010; 3, no. 16, pp. 431

11. Murthy, K.R.S., Sushruta Samhita, Chaukhambha orientalia, Varanasi, India, Kalpasthan, 2010; 3, no. 17, pp. 431

12. https://www.easyayurveda.com/2019/04/11/lakshalaccifer-laccal 
13. Arya Neelam, Sharma Anita, 'A Review ArticlePharmacological and therapeutic properties of vicharchikari tail'et.al, Int. J. Res. Ayurveda pharm, sep-oct 2016; 7(5).

14. Krup V, Prakash LH, Harini A (2013) Pharmacological Activities of Turmeric (Curcuma longa Linn): A Review. J Homeop Ayurv Med 2:133.

15. M. Nagarajan, Gina R. Kuruvilla, K. Subrahmanya Kumar, Padma Venkatasubramanian 'Pharmacology of Ativisha, Musta and their substitutes'J Ayurveda Integr Med. 2015 Apr-Jun; 6(2) 121-133

16. Gupta $\mathrm{PC}$, 'Biological and pharmacological properties of terminalia chebula Retz. (haritaki)'- An overview. International journal of pharmacy and pharmaceutical sciences ISSN- 0975-1491 vol 4, suppl 3, 2012

17. Bano Uzma, Jabeen Azhar, Ahmed Asrar, Siddiqui M. Akhtar. A review article- 'Therapeutic Uses of Vitex Nigundo' World Journal of Pharmaceutical Research, vol-4, Issue12,589-606

18. Kumar S,Kumari R Traditional, Phytochemical and Biological Activities of Elettaria Cardamomum (L.) Maton - A Review ISSN (Online): 0975-8232

19. Sundaresan N and Ilango K. Review on Valeriana Species- Valeriana wallichii and Valerianajatamansi, et al /J. Pharm. Sci. \& Res. Vol. 10(11), 2018, 2697 2701

20. Devi V S, Rao M G. Valeriana Wallichii - A Rich Aroma Root Plant - A Review, World Journal of Pharmacy and Pharmaceutical Sciences, Volume 3, Issue $9,1516-1525$.

21. https://www.verywellhealth.com/the-benefits-ofsaussurea-88648

22. Zahara K, Tabassum S, Sabir S, Arshad M, Qureshi R, Amjad MS, Chaudhari SK. A review of the therapeutic potential of Saussurea lappa-An endangered plant from the Himalayas. Asian Pac J Trop Med 2014; 7(Suppl 1): S60-S69

23. Soni RK, Dixit V, Irchhaiya R and Alok S.Callicarpa Macrophylla: A Review Update On Its Botany, Ethnobotany, Phytochemistry And Pharmacology. et al., IJP, 2014; Vol. 1(2): 87-94.

24. Tripathi B., Charaka Samhita. Chaukhambha orientalia, Varanasi, India, Chikitsasthan, 2013; 23, no. 98100, pp. 767-768

25. Nautiyal, C.S., Chauhan, P.S., Nene, Y.L. Medicinal smoke reduces airborne bacteria. Journal of Ethnopharmacology, 2007; 114(3): 446- 451

26. Sharma, P.K., Ayub, S., Tripathi, C.N., Dubey, S.K. Agnihotra - A non-conventional solution to Air pollu- tion. International Journal of Innovative Research in Science \& Engineering, 2014; vol. 2

27. Lad, N., Palekar, S. Preparation and evaluation of Herbal Dhoop for cleansing the air. International Journal of Herbal medicine, 2016; 4(6): 98-103

28. https://www.aparnaconstructions.com/best-indoorplants-for-removing-air-pollutants/

29. Kaviraj Ambika dutta Shastri, editor Ayurveda Tattva Sandipika Hindi commentary of Sushruta Samhita of Maharshi Sushruta $-1^{\text {st }}$ part, Chikitsa Sthana chapter40 verse 21. Varanasi: Chaukumba Surbharati Sansthana Reprinted; 2014. p.224

30. Dr Smt. Shailaja Srivastava, Jiwanprada Hindi Commentator of Sharngadhara Samhita of Acharya Sharagdhara, Uttara Khanda Chapter 8 verse 2,11,24. Varanasi: Chaukhambha Orientalia; Reprinted 2013.p.394,400,402

31. Prof. (Dr) SatyendraPrakashMishra, Yoga and Ayurveda, Art\& ethics of yoga, choukhamba publication,2015, Chapter no 4, page no 49

32. Gherand Samhita: Dr Chamanlal Gautam, Sanskrit Sansthan, Bareli Reprint edition, 2003

33. Hatha Yog Pradipika, Swami Muktibodhananda, Publication Trust, Yoga, Munger, Bihar, First Edition, 1985;2: 7-13

\section{Source of Support: Nil Conflict of Interest: None Declared}

How to cite this URL: Jayanti Jain et al: Purification Of Air By Lakshaharidraadi Yoga And Some Measures To Reverse The Impact Of Polluted Air. International Ayurvedic Medical Journal \{online\} 2021 \{cited September 2021\} Available from: http://www.iamj.in/posts/images/upload/2201_2208.pdf 